\title{
Communication
}

[Comunicação]

\section{Seroprevalence of toxoplasma gondii infection in goats in the five northwestern provinces of China}

\author{
[Seroprevalência de infecção por toxoplasma gonddi em cabras nas cinco \\ províncias do noroeste da China]

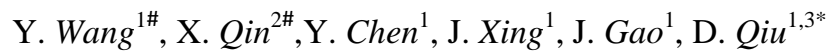 \\ ${ }^{1}$ College of Animal Science - Tarim University, China \\ ${ }^{2}$ College of Agriculture - Liaocheng University - Liaocheng, China \\ ${ }^{3}$ Huazhong Agricultural University - Wuhan - Hubei Province, China
}

Toxoplasma gondii (T. gondii), a parasitic zoonosis that belongs to the phylum Apicomplexa, can infect most warm-blooded animals worldwide, including mammals and birds (Dubey, 1996; Klun et al., 2006; Opsteegh et al., 2010; Salant et al., 2009; Zhao et al., 2011). The disease caused by $T$. gondii is of veterinary and medical importance, because it may cause abortion or congenital disease in its intermediate hosts (Salant et al., 2009). As one of the intermediate hosts, infected goat not only results in apparent reproductive losses, but also presents an important source of human infection through consumption of infected mutton(Innes et al., 2009; Zhao et al., 2011).Goats are an important source of meat for humans(Santana et al., 2013). Lamb and mutton are considered important sources of $\mathrm{T}$. gondii infection in humans (Iovu et al., 2012; Opsteegh et al., 2010).

Humans are infected postnatal mainly through ingestion of tissue cysts from undercooked meat or oocysts from the environment contaminated by infected mammals' feces (Dubey et al., 2004). In addition, infection with $T$. gondii is usually present either asymptomatic or with mild flu-like symptoms. Furthermore, if the gravida is infected during pregnancy, toxoplasmosis can lead to abortion or congenital malformations affecting the brain, eyes, or other fetal organs (Halos et al., 2010). The "five northwestern provinces" is used to name the Northwest Region, originated by the

Recebido em 25 de março de 2019

Aceito em 18 de junho de 2019

\# These authors equally contributed to the present study

*Autor para correspondência (corresponding author)

E-mail: dxqiucn@mail.hzau.edu.cn six administrative regions established from 19491953, including Xinjiang Uygur Autonomous Region, Qinghai Province, Gansu Province, Shanxi Province and Ningxia Province. There are more Islam believers in the five provinces than any other provinces in China, therefore, consumptions of lamb are more popular. However, few studies on the prevalence of T.gondii in goat have been conducted in these provinces since 1979 according to the Chinese National Knowledge Infrastructure and PubMed. The current study aimed to determine the seroprevalence of $T$. gondii infection in goats in this region to estimate the risk factors associated with exposure to the pathogen.

Serums with detailed records were randomly selected for this study. A total of 928 goat serums were collected from Xinjiang Uygur Autonomous Region, Qinghai Province, Gansu Province, Shanxi Province and Ningxia Province. T. gondii was determined using a commercial ELISA kit from Lanzhou Veterinary Research Institute of Chinese Academy of Agricultural Sciences for goat according to the recommendations of the manufacturer. Positive and negative control sera were supplied within the ELISA kit. The tests were performed in the College of Animal Science, Tarim University. Briefly, a 96-well ELISA plate was coated with T. gondii-specific antigens. After incubating the diluted serum sample (1:100) was added into the test well, after incubation and a subsequent washing step, a conjugate was added. The plate 
was washed again, then, a chromogenic enzyme substrate was added. The optical density (OD) at $450 \mathrm{~nm}$ was measured by a spectral photometer. A reaction was considered to be positive when the value was more than two folds of the standard negative serum.

Data were analyzed $\left(\chi^{2}\right.$-test) using the statistical software package SPSS version 17.0 (SPSS, Inc, Chicago, IL, USA). The risk factors included sex, age and province in the present survey. Identification of a risk factor required a $95 \%$ confidence level $(\mathrm{P}<0.05)$ as well as a biologically plausible association between the factor and seroprevalence of $T$. gondii.

\section{RESULTS}

The results of the survey were shown in Table 1 . Among the 928 goat samples, 197 were positive by ELISA. Seroprevalence in male goat $(13.83 \%, 13 / 94)$ was significantly lower than that in female $(\mathrm{P}=0.048 ; \mathrm{OR}=0.567,95 \% \mathrm{CI}=0.309$ to 1.041). Statistical analysis revealed that significant differences were observed in the $\geq 2$ groups $(\mathrm{P}=0.002, \mathrm{OR}=0.330,95 \% \mathrm{CI}=0.224$ to 0.488$)$. The prevalence of $T$. gondii infection in terms of province group was $21.59 \%(65 / 301)$, $18.40 \% \quad(23 / 125), 20.96 \% \quad(35 / 167), 22.63 \%$ (43/190) and $21.38 \%(31 / 145)$ in Xinjiang Uygur Autonomous Region, Qinghai Province, Gansu
Province, Shanxi Province and Ningxia Province, respectively. No statistical difference was found among different provinces.

\section{DISCUSSION}

This is the first epidemiological study on T.gondii infection in goats in the five northwestern provinces of China. In general, the overall seroprevalence $(21.23 \%)$ was lower than that in many other domestic surveys. Many surveys on goat infection with $T$. gondii have been reported in different parts of China. For example, the prevalence in goats was $41.18 \%$ in GuiLin (LAT) (Mo et al., 1993), 27.9\% in DanYang (IHA) (Yang et al., 1997) and 39.13\% in Beijing (MAT) (Wang et al., 2006). These differences may be explained by the different test methods used, survey periods, sample sizes, and cutoff values (Faria et al., 2007). Domestic research was mostly performed using indirect hemagglutination antibody (IHA) test or modified agglutination test (MAT). IHA has poor resolution and sensitivity compared to ELISA (Dubey et al., 1995). On the other hand, MAT may detect antibodies that appear at the early stage of infection against components of tachyzoite membrane (Hirvela-Koski, 1990). A comparative study using several serologic tests indicated that indirect ELISA is the most sensitive method (Hill et al., 2006).

Table 1. Seroprevalence of T. gondii infection in Goat in Xinjiang Uygur Autonomous Region, Qinghai Province, Gansu Province, Shanxi Province and Ningxia Province determined by ELISA

\begin{tabular}{|c|c|c|c|c|c|}
\hline Factor & Category & No. examed & No. positive(\%) & Odds ratio(95\%CI) & $\mathrm{P}$ \\
\hline \multirow[t]{2}{*}{ Sex } & Male & 94 & $13(13.83)$ & 1 & \\
\hline & Female & 834 & $184(22.06)$ & $0.567(0.309-1.041)$ & 0.048 \\
\hline \multirow[t]{2}{*}{ Age } & $<2$ & 331 & $36(10.88)$ & 1 & \\
\hline & $\geq 2$ & 597 & $161(26.97)$ & $0.330(0.224-0.488)$ & 0.002 \\
\hline \multirow[t]{6}{*}{ Province } & Xinjiang & 301 & $65(21.59)$ & 1 & \\
\hline & Qinghai & 125 & $23(18.40)$ & $1.221(0.720-2.074)$ & 0.907 \\
\hline & Gansu & 167 & $35(20.96)$ & $1.039(0.654-1.650)$ & 0.843 \\
\hline & Shanxi & 190 & $43(22.63)$ & $0.942(0.608-1.457)$ & 0.688 \\
\hline & Ningxia & 145 & $31(21.38)$ & $1.013(0.625-1.641)$ & 0.955 \\
\hline & Total & 928 & $197(21.23)$ & & \\
\hline
\end{tabular}

In this survey, we found that one risk factor for T. gondii infection in goat was gender. Seroprevalence in females was significantly higher than that in males. Similar results were also shown in other studies in Thailand (Jittapalapong et al., 2005), Saudi Arabia (Sanad and Al-Ghabban 2007), Romania (Iovu et al., 2012) and Ethiopia (Teshale et al., 2007). The reason might be that female animals are more susceptible to the infection of protozoan parasites (Alexander and Stimson, 1988).

The other risk factor for $T$. gondii infection in goat found in the present study was age. Significant differences were observed in the $\geq 2$ group $(\mathrm{P}=0.047, \mathrm{OR}=0.774,95 \% \mathrm{CI}=0.405$ to 1.482). It's also consistent with previous reports 
in Romania (Iovu et al., 2012), Ethiopia (Teshale et al., 2007), Portugal (Lopes et al., 2013), Nigeria (Kamani et al., 2010), Mexico (Alvarado-Esquivel et al., 2009) and Brazil (Ragozo et al., 2009). Seroprevalence in adult goat was higher than that in lambs. Adult animals may be more exposed to the parasite and for a longer time through the oral route of transmission than the young (Halos et al., 2010; Lunden et al., 1994; Opsteegh et al., 2011; van der Puije et al., 2000).

Keywords: Toxoplasma gondii, seroprevalence, goat, five northwestern provinces

\section{RESUMO}

O objetivo do presente estudo foi investigar a soroprevalência de infecção com Toxoplasma gondii (T. gondii) em cabras em cinco províncias do noroeste da China. Soroprevalência foi determinado usando o kit de teste de ensaio de imunoabsorção enzimática(ELISA). A soroprevalência geral foi $21.23 \%$ (197/928). Análise estatística revlou que diferenças significativas foram observadas em fêmeas $(P=$ $0.048, O R=0.567,95 \% C I=0.309$ a 1.041$)$ e nos grupos $\geq 2(P=0.002, O R=0.330,95 \% C I=0.224 a$ 0.488). Nenhuma diferença estatisticamente significativa foi observada entre diferentes províncias. Nossos resultados indicam que a infecção com $\mathrm{T}$. gondii, que pode ter implicações importantes sobre a saúde pública, teve diferenças significativas em sexo e idade, mas nenhuma significância foi observada em diferentes regiões. Além disto, nossos resultados também indicam que infecção por T. gondii em cabras é generalizada nas cinco províncias do noroeste.

Palavras-chave:Toxoplasma gondii, soroprevalência, cabra, cinco províncias do noroeste

\section{REFERENCES}

ALEXANDER, J.; STIMSON, W. Sex hormones and the course of parasitic infection. Parasitol. Today, v.4, p.189-193, 1988.

ALVARADO-ESQUIVEL, C.; TORRESCASTORENA, A.; LIESENFELD, O. et al. Seroepidemiology of Toxoplasma gondii infection in pregnant women in rural Durango, Mexico. J. Parasitol., v.95, p.271-274, 2009.

DUBEY, J. Strategies to reduce transmission of Toxoplasma gondii to animals and humans. Vet. Parasitol., v.64, p.65-70, 1996.

DUBEY, J.; SALANT, H.; SREEKUMAR, C. et al. High prevalence of Toxoplasma gondii in a commercial flock of chickens in Israel, and public health implications of free-range farming. Vet. Parasitol., v.121, p.317-322, 2004.

DUBEY, J.; THULLIEZ, P.; WEIGEL, R. et al. Sensitivity and specificity of various serologic tests for detection of Toxoplasma gondii infection in naturally infected sows. Am. J. Vet. Res., v.56, p.1030, 1995.

FARIA, E.; GENNARI, S.; PENA, H. et al. Prevalence of anti-Toxoplasma gondii and antiNeospora caninum antibodies in goats slaughtered in the public slaughterhouse of Patos city, Paraiba State, Northeast region of Brazil. Vet. Parasitol., v.149, p.126-129, 2007.
HALOS, L.; THEBAULT, A.; AUBERT, D. et al. An innovative survey underlining the significant level of contamination by Toxoplasma gondii of ovine meat consumed in France. Int. J. Parasitol., v.40, p.193-200, 2010.

HILL, D.; CHIRUKANDOTH, S.; DUBEY, J. et al. Comparison of detection methods for Toxoplasma gondii in naturally and experimentally infected swine. Vet. Parasitol., v.141, p.9-17, 2006.

HIRVELA-KOSKI, V. Evaluation of ELISA for the detection of Toxoplasma antibodies in swine sera. Acta. Vet. Scand., v.31, p.413-422, 1990.

INNES, E.; BARTLEY, P.; BUXTON, D. et al. Ovine toxoplasmosis. Parasitology, v.136, p.1887, 2009.

IOVU, A.; GYORKE, A.; MIRCEAN, V. et al. Seroprevalence of Toxoplasma gondii and Neospora caninum in dairy goats from Romania. Vet. Parasitol., v.186, p.470-474, 2012.

JITTAPALAPONG， S.; SANGVARANOND, A.; PINYOPANUWAT, N. et al. Seroprevalence of Toxoplasma gondii infection in domestic goats in Satun Province, Thailand. Vet. Parasitol., v.127, p.17-22, 2005. 
KAMANI, J.; MANI, A.; EGWU, G. Seroprevalence of Toxoplasma gondii infection in domestic sheep and goats in Borno state, Nigeria. Trop. Anim. Health. Prod., v.42, p.793797, 2010.

KLUN， I.; DJURKOVIC-DJAKOVIC， O.; KATIC-RADIVOJEVIC, S. et al. Crosssectional survey on Toxoplasma gondii infection in cattle, sheep and pigs in Serbia: seroprevalence and risk factors. Vet. Parasitol., v.135, p.121-131, 2006.

LOPES, A.; DUBEY, J.; NETO, F. et al.Seroprevalence of Toxoplasma gondii infection in cattle, sheep, goats and pigs from the North of Portugal for human consumption. Vet. Parasitol., v.193, p.266-269, 2013.

LUNDEN, A.; NASHOLM, A.; UGGLA, A. Long-term study of Toxoplasma gondii infection in a Swedish sheep flock. Acta. Vet. Scand., v.35, p.273, 1994.

OPSTEEGH, M.; TEUNIS, P.; MENSINK, M. et al. Evaluation of ELISA test characteristics and estimation of Toxoplasma gondii seroprevalence in Dutch sheep using mixture models. Prev. Vet. Med., v.96, p.232-240, 2010.

OPSTEEGH, M.; TEUNIS, P.; ZUCHNER, L. et al. Low predictive value of seroprevalence of Toxoplasma gondii in cattle for detection of parasite DNA. Int. J. Parasitol., v.41, p.343-354, 2011.
RAGOZO, A.; YAI, L.; OLIVEIRA, L. et al. Solation of Toxoplasma gondii from goats from Brazil. J. Parasitol., v.95 p.323-326, 2009.

SALANT, H.; LANDAU, D.; BANETH, G. A cross-sectional survey of Toxoplasma gondii antibodies in Israeli pigeons. Vet. Parasitol., v.165, p.145-149. 2009.

SANAD, M.; AL-GHABBAN, A. Serological survey on toxoplasmosis among slaughtered sheep and goats in Tabouk, Saudi Arabia. J. Egypt. Soc. Parasitol., v.37, p.329, 2007.

SANTANA, L.; ROSSI, G.; GASPAR, R. et al. Evidence of sexual transmission of Toxoplasma gondii in goats. Small Ruminant Res., v.115, p.130-133, 2013.

TESHALE, S.; DUMETRE, A.; DARDE, M. et al. Serological survey of caprine toxoplasmosis in Ethiopia: prevalence and risk factors. Parasite, v.14, p.155-159, 2007.

VAN, D.; BOSOMPEM, K.; CANACOO, E. et al. The prevalence of anti-Toxoplasma gondii antibodies in Ghanaian sheep and goats. Acta. Trop., v.76, p.21-26,2000.

ZHAO, G.; ZHANG, M.; LEI, L. et al. Seroprevalence of Toxoplasma gondii infection in dairy goats in Shaanxi Province, Northwestern China. Parasit. Vectors, v.4, p.47, 2011. 